\title{
Effects of Urban Stormwater Control Measures on Denitrification in Receiving Streams
}

\author{
Erin N. Rivers ${ }^{1}$, Sara K. McMillan ${ }^{2, * \mathbb{D}}$, Colin D. Bell ${ }^{3} \mathbb{D}$ and Sandra M. Clinton ${ }^{4}(\mathbb{D}$ \\ 1 School of the Environment, Portland State University, 1719 SW 10th Ave., Portland, OR 97201, USA; \\ elooper@pdx.edu \\ 2 Department of Agricultural and Biological Engineering, Purdue University, 225 S. University St., \\ West Lafayette, IN 47907, USA \\ 3 Department of Civil and Environmental Engineering, Colorado School of Mines, 1500 Illinois St., \\ Golden, CO 80401, USA; cdbell@mines.edu \\ 4 Department of Geography and Earth Sciences, University of North Carolina at Charlotte, 9201 University \\ City Blvd., Charlotte, NC 28223, USA; sclinto1@uncc.edu \\ * Correspondence: mcmill@purdue.edu
}

Received: 28 September 2018; Accepted: 28 October 2018; Published: 5 November 2018

\begin{abstract}
Urban areas are increasingly adopting the use of ecologically-based technologies for stormwater management to mitigate the effects of impervious surface runoff on receiving water bodies. While stormwater control measures (SCMs) reduce runoff, their ability to influence ecosystem function in receiving streams is not well known. To understand the effect of SCMs on net ecosystem function in stream networks, we measured sediment denitrification in four streams across a gradient of urban and suburban residential development in Charlotte, NC. We evaluated the influence of SCM inputs on actual (DNF) and potential (DEA) denitrification activity in stream sediments at the SCM-stream confluence to quantify microbial processes and the environmental factors that control them. DNF was variable across sites, ranging from $0-6.60 \mathrm{mg}-\mathrm{N} \cdot \mathrm{m}^{-2} \cdot \mathrm{h}^{-1}$ and highly correlated with in-stream nitrate $\left(\mathrm{NO}_{3}-\mathrm{N}\right)$ concentrations. Sites with a greater impervious area showed a pattern of significantly higher DEA rates upstream of the SCM compared to downstream, while sites with less imperviousness showed the opposite trend. We hypothesize that this is because of elevated concentrations of carbon and nitrogen provided by pond and wetland outflows, and stabilization of the benthic habitat by lower peak discharge. These results suggest that SCMs integrated into the watershed have the potential to create cascading positive effects on in-stream nutrient processing and thereby improve water quality; however, at higher levels of imperviousness, the capacity for SCMs to match the scale of the impacts of urbanization likely diminishes.
\end{abstract}

Keywords: nitrogen; stormwater control measures; denitrifying enzyme activity; denitrification; urban streams

\section{Introduction}

Urbanization is a rapidly growing form of land use change throughout the world. Urban impervious surfaces and associated stormwater collection systems circumvent infiltration in upland and riparian zones, causing changes in urban stream flow regimes that lead to flashier hydrographs, increased peak flows, shorter rainfall-discharge lag times, and increased mobilization of chemical pollutants within the watershed [1-3]. These hydrologic changes lead to changes in water quality, channel morphology, ecology, and a reduction in the resilience of the stream ecosystem to altered urban hydrologic and water quality regimes $[4,5]$. This results in water quality and ecological integrity of streams that are negatively correlated with urbanization with more than $130,000 \mathrm{~km}$ of streams and rivers in the United States impacted by this impairment [6-10]. 
The net effects of altered hydrology on stream geomorphology are increased erosional and scouring processes, leading to decreased channel heterogeneity and a more simplified, uniform morphology that can affect sediment properties such as sediment texture (less fines) and carbon (C) content through decreased C buildup [11]. Changes in these sediment properties thereby alter microbial composition, leading to subsequent changes in biogeochemical transformations such as denitrification (microbial conversion of nitrate $\left(\mathrm{NO}_{3}-\mathrm{N}\right)$ to nitrogen gas $\left(\mathrm{N}_{2}\right)$ ) [12]. Denitrification is controlled primarily by $\mathrm{NO}_{3}-\mathrm{N}$ availability, dissolved oxygen concentration, and organic $\mathrm{C}$ availability [13], and benthic sediments foster conditions favorable to the removal of $\mathrm{N}$ via denitrification [14]. Secondary environmental variables, including temperature, sediment grain size, type of substrata, land use, and hydrology, also affect the condition of the sediment habitat, thereby influencing the capacity for denitrification [15]. Low erosion rates and high stability of channel sediments facilitate the retention of organic $\mathrm{C}$ sources, microbial community growth and activity, and oxygen consumption via heterotrophic metabolism, all of which enhance denitrification $[16,17]$.

Stormwater control measures (SCMs) are a management practice implemented to regulate urban stormwater runoff and improve the ecological condition of receiving streams [18]. SCMs are end-of-pipe detention structures placed in the landscape with the primary goal of intercepting runoff from impervious areas before it reaches the stream channel $[3,19]$. Some commonly constructed structures include wet and dry detention ponds, constructed wetlands, bioretention areas, and rain gardens. These structures store runoff during precipitation events and infiltrate or slowly release the water to the receiving stream. The retention and slow release of stormwater promote the attenuation of peak flows and extend the length of the hydrograph recession [20]. Together, these alterations to the storm hydrograph reduce the energy inputs to the channel from runoff, decrease erosion potential, and increase channel stability [21]. Additionally, SCMs can retain sediments, nutrients, and contaminants, which can influence receiving stream chemistry [22].

When comparing SCM performance by monitoring inflow and outflow concentrations and flow, several studies have shown variable but significant reductions in sediment and dissolved inorganic nutrient concentrations [23-27]; however, performance monitoring typically ends at the outlet and does not extend into receiving the stream. SCMs create new flow connections throughout the watershed and specifically new confluences where SCM outflow mixes with receiving streams. Confluences act as ecosystem control points for biogeochemical reactions [28], previously described as hot spots/hot moments [29], and are known to be important for multiple ecosystem functions and services [30]. Nutrient concentrations increase at confluences, due to higher concentration water from tributaries mixing with low concentration mainstem water, and often remain elevated further downstream [31,32]. Furthermore, these increases directly below confluences can impact biotic communities (e.g., biofilms, fish) due to the physico-chemical changes that occur from mixing [31]. Thus, confluences can act to change the pattern of upstream-downstream processes occurring along the stream continuum in both a positive and negative manner [32]. To date, little attention has been given to understanding how these new urban confluences (i.e., SCM-stream) affect ecosystem processes in the receiving stream.

The type of SCM constructed (e.g., wet pond, wetland) as well as the age, level of maintenance, and design standards will affect individual performance with subsequent impacts on the concentrations and timing of export of water, nutrients, carbon, and other pollutants to the stream [33]. Watershed scale drivers, such as the characteristics of urban development (e.g., impervious surface coverage and distribution, age of the development, land use) and the location of the SCM relative to both urban impervious surfaces and other SCMs (e.g., alone or in series), will also regulate the SCM's impact on the stream ecosystem [26,34,35]. Denitrifying organisms serve as useful indicators for understanding ecosystem responses in streams affected by urbanization because they are ubiquitous in stream sediments, phylogenetically diverse, metabolically facultative, and mediate transformations in the nitrogen cycle. Moreover, denitrification is the only mechanism for the permanent removal of bioavailable nitrate, and denitrifying organisms therefore play a key role in mitigating eutrophication, growth of harmful algal blooms, and large zones of hypoxia [36,37]. 
In this study, we focus on denitrification as an indicator of the effect of SCM inputs on net ecosystem function in receiving streams because $\mathrm{N}$ pollution is a common concern in urban stream systems and denitrification is the only process that removes $\mathrm{N}$ from the system. We hypothesized that new urban confluences created by SCMs within the stream network will synergistically enhance watershed scale function by increasing microbially driven processes, such as denitrification, in the stream itself. A suite of methodological approaches exist to quantify denitrification and each addresses different questions and controlling environmental factors [38]. Here, we measured actual denitrification rates (DNF) and potential denitrification rates (DEA, denitrifying enzyme activity) to estimate in situ denitrification as well as the total capacity of the in-stream microbial community to denitrify, respectively. DNF represents an estimate of in situ rates based on the existing conditions of the local environment that influence the proximal controls on denitrification (i.e., water $\mathrm{NO}_{3}-\mathrm{N}$ and $\mathrm{C}$ concentrations, sediment organic matter, oxygen content), and DEA measures the activity of denitrifying enzymes at the time of sampling and is reflective of the environmental factors that drive the expression of the denitrifying enzymes [38]. Addition of nutrients in the DEA assay removes limitations within the sediment microbial community and allows for the characterization of differences in microbial activity among sites independent of ambient conditions. DEA rates represent the maximum potential for denitrification, allowing for a comparison across a range of environmental conditions [39]. Therefore, DEA is an integrative measurement of the microbial biomass present as well as the long-term environmental conditions that influence the growth and function of the microbial community whereas DNF allows us to approximate current, in situ processes [23].

We evaluated the influence of SCM inputs on actual and potential denitrification activity in stream sediments at the SCM-stream confluence to quantify microbial processes and the environmental factors that control them. We did so in streams across a gradient of urban and suburban residential development and to determine the singular and cumulative effects of multiple SCM inputs on stream sediment biogeochemistry. We hypothesized that SCMs would enhance ecological functions by reducing erosive forces of stormwater runoff and altering stream chemistry. Specifically, we addressed the following questions: (1) Do SCMs influence denitrification processes downstream of the stream-SCM confluence? (2) Does the influence of a SCM on denitrification processes in the receiving stream vary as a function of imperviousness, SCM type, or both, as these factors have been shown to control hydrologic and water quality degradation?

\section{Methods and Analysis}

\subsection{Study Sites}

Four headwater streams that receive stormwater discharge from SCMs in Charlotte, NC, USA were selected for this study (Figure 1). In Charlotte, average monthly temperatures ranged from $5.4{ }^{\circ} \mathrm{C}$ to $26.8^{\circ} \mathrm{C}$, and mean annual precipitation was $1105 \mathrm{~mm}$ (data from 1971-2000) [40]. Summer precipitation is characterized by high-intensity, short thunderstorms while winter precipitation is characterized by low-intensity, prolonged rainfall [40]. Soils are composed of primarily sandy loam and sandy clay loam [41].

The four streams were named with descriptive, two-letter codes where the first letter is based on the development category of the watershed (U for urban, and $\mathrm{S}$ for suburban), and the second letter was based on the type of SCM around which the stream-SCM confluence was monitored (P for wet pond, L for wetland). As an example, the stream "UP" has an urban watershed (U), and we monitored the stream around a confluence with outflow from a wet pond (P) SCM. In this way, the four sites covered all four development type-SCM pairs. Urban watersheds consisted of commercial, high-density residential, and medium residential land uses, and were completely built out in the 1950's. Suburban watersheds were characterized by very little commercial use, and low to medium density residential land uses. Development occurred from 2004-2008 and remained relatively stable throughout the monitoring period (2011-2014). 


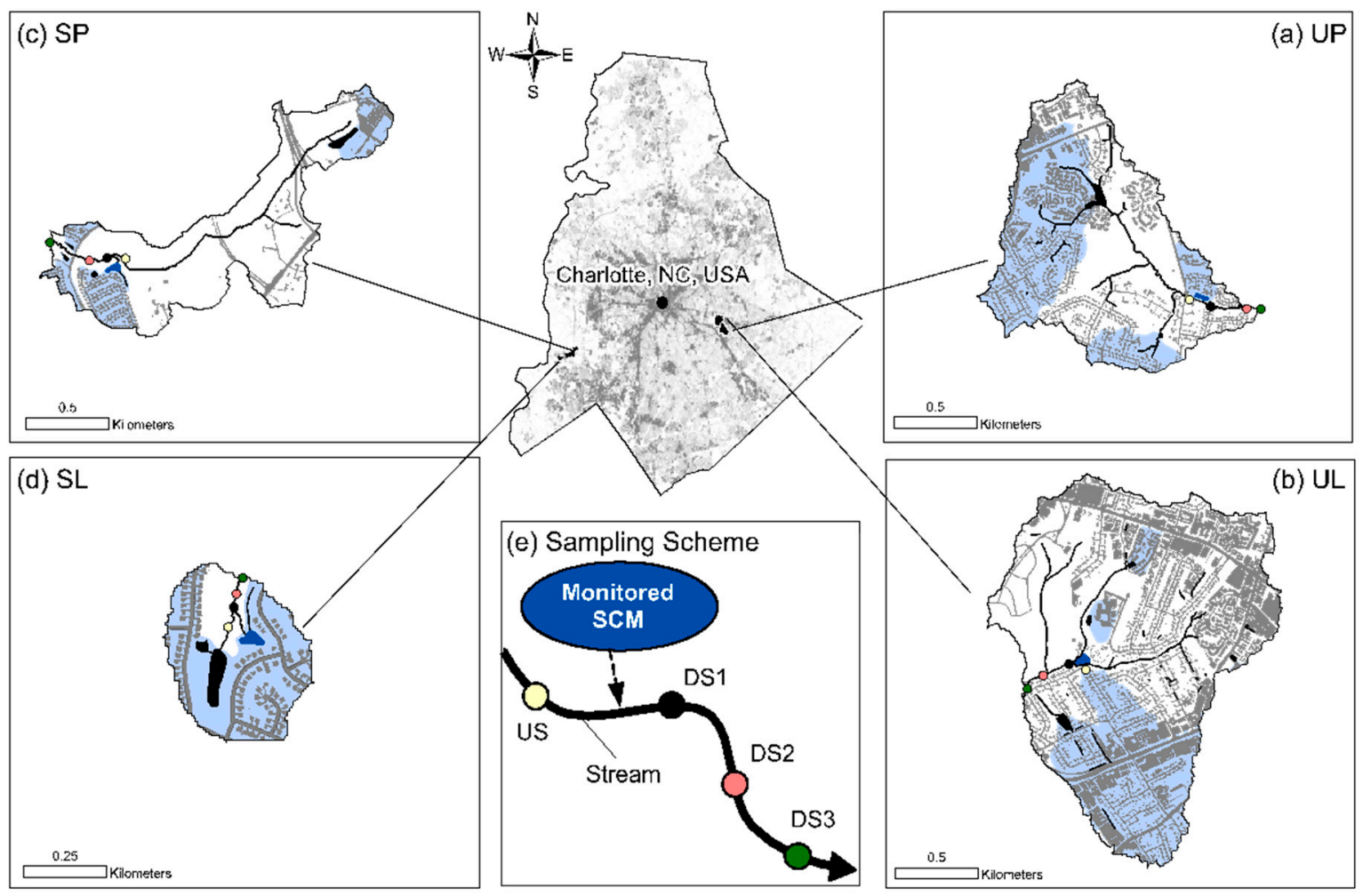

Legend: - Streams $\square$ SCMs $\square$ Monitored SCM $\square$ Impervious Area $\square$ SCM Treated Area OUS - DS1 ODS2 ODS3

Figure 1. Locations of the four monitored watersheds in Charlotte, North Carolina, USA. Watershed maps of (a) UP (urban wet pond), (b) UL (urban wetland), (c) SP (suburban wet pond), (d) SL (suburban wetland) show the location of impervious surfaces, stormwater control measures (SCMs), areas served by the SCMs, and surface drainage networks, and (e) sampling locations upstream and downstream of the confluence of the SCM outlet and the stream channel. Note: the inset map in panel (e) is at a smaller scale than the remaining panels.

In each stream, we established four sampling locations around the SCM confluence: immediately upstream (US) of the SCM confluence, approximately $20 \mathrm{~m}$ downstream of the SCM (DS1), and two additional locations further downstream of the confluence (DS2 and DS3, respectively; Figure 1).

The 16 monitored locations (4 locations per stream) were named using the stream's two letter code, followed by the code of the location relative to the SCM (e.g., the first site downstream of the wet pond at the urban site was named UP-DS1). Although these locations were nested and near to one another, each of these in-stream locations had different watershed characteristics due inputs from additional surface runoff, natural and engineered tributaries, and SCM outflow (Table 1). Schematics of these additional hydrologic inputs relative to the sampling locations for all four streams are shown in Figure 2. Discharge was measured at the DS1 monitoring location for a companion study by Bell et al. [35]. 
Table 1. Description of SCM type, watershed development, and stream characteristics for each of the four sites.

\begin{tabular}{|c|c|c|c|c|c|c|}
\hline Receiving Stream & SCM Type & Land Development & Monitoring Location & Total Drainage Area (ha) & $\begin{array}{c}\text { Watershed } \\
\text { Imperviousness (\%) }\end{array}$ & Average Discharge (L/s) \\
\hline \multirow[t]{4}{*}{ Urban wet pond (UP) } & \multirow{4}{*}{ Wet detention pond } & \multirow{4}{*}{ Urban 1950s } & Upstream (US) & 142 & 26 & \multirow{4}{*}{12.4} \\
\hline & & & Downstream-1 (DS1) & 145 & 27 & \\
\hline & & & Downstream-2 (DS2) & 151 & 27 & \\
\hline & & & Downstream-3 (DS3) & 152 & 27 & \\
\hline \multirow[t]{4}{*}{ Urban wetland (UL) } & \multirow{4}{*}{ Constructed wetland } & \multirow{4}{*}{ Urban 1950s } & US & 83 & 46 & \multirow{4}{*}{13.5} \\
\hline & & & DS1 & 144 & 43 & \\
\hline & & & DS2 & 190 & 37 & \\
\hline & & & DS3 & 253 & 37 & \\
\hline \multirow[t]{4}{*}{ Suburban wet pond (SP) } & \multirow{4}{*}{ Wet detention pond } & \multirow{4}{*}{ Suburban 2004-present } & US & 101 & 12 & \multirow{4}{*}{6.3} \\
\hline & & & DS1 & 111 & 14 & \\
\hline & & & DS2 & 119 & 14 & \\
\hline & & & DS3 & 129 & 18 & \\
\hline \multirow[t]{4}{*}{ Suburban wetland (SL) } & \multirow{4}{*}{ Constructed wetland } & \multirow{4}{*}{ Suburban 2004-present } & US & 8.7 & 24 & \multirow{4}{*}{1.1} \\
\hline & & & DS1 & 14.7 & 24 & \\
\hline & & & DS2 & 16.9 & 23 & \\
\hline & & & DS3 & 17.5 & 22 & \\
\hline
\end{tabular}




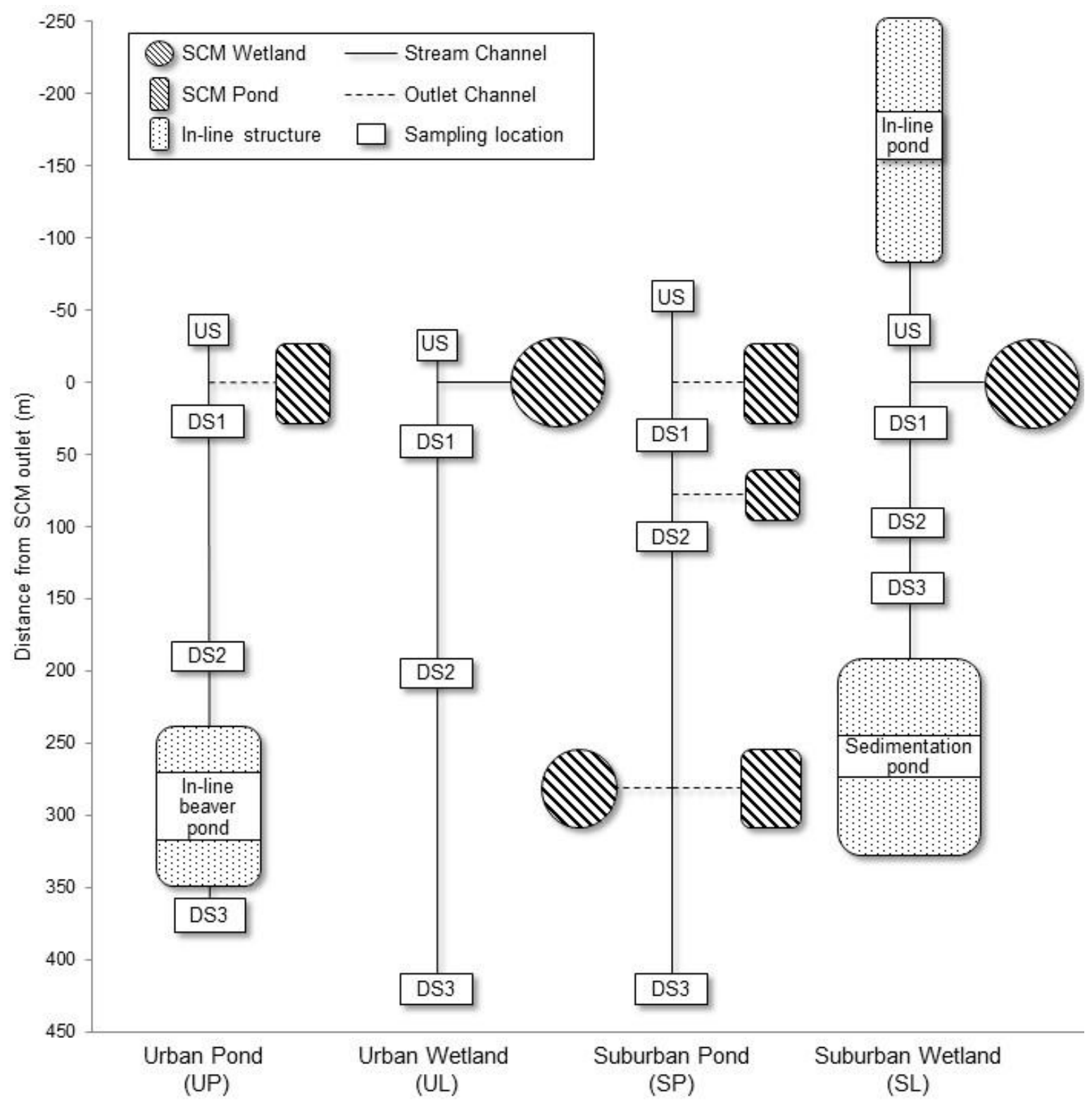

Figure 2. Schematic of the site configurations at urban pond (UP), urban wetland (UL), suburban pond (SP), and suburban wetland (SL) showing all SCM inputs, sampling locations, and additional stream features. Stream distances of sampling locations upstream (US) and downstream (DS1, DS2, and DS3) relative to the confluence of the SCM outlet are indicated on the y-axis, and sites are listed along the x-axis. SCMs were connected to the streams through connecting pipes or connecting stream channels. Negative values indicate distances upstream of the SCM outlet, and positive values indicate distances downstream of the SCM outlet. While distances are to scale, the sizes of features are not to scale, and shapes do not represent actual morphology of structures.

The UP stream reach was restored in 2010, which resulted in engineered pool-riffle geomorphology, predominately clay bed substrate (especially in the pools), and relatively little sinuosity. Because of the restoration, the riparian vegetation primarily consisted of grasses associated with early succession, so only the occasional, large deciduous tree offered shade to the channel. In addition to the wet pond that was the focus of this study, there are two SCMs upstream of the study reach, including a large inline pond and a restored wetland. An inline beaver pond developed at the downstream end of our study reach between DS2 and DS3 after a sampling event in summer 2013 (Figure 2). 
Similar to the UP reach, the channel geomorphology at UL consisted of engineering pool-riffle geomorphology and low sinuosity, although the substrate here was much coarser: consisting of sand and pebbles. Riparian vegetation was an early growth forest that offered some shade, but rarely spanned the entire channel. Three additional SCMs exist in the UL watershed upstream of the study reach, which was also restored in 2003.

The SP stream reach was highly incised, having eroded to bedrock with pool-riffle geomorphology. The substrate in the riffles was typically exposed bedrock, overlain with pockets of sand and fine pebbles, whereas the pools typically had $10-20 \mathrm{~cm}$ of fine sand and silt on top of bedrock. The SP stream ran through a riparian forest preserved during development of the watershed that offered complete shade during leaf out. This forest also contributed large leaf litter inputs to the stream in the autumn. Multiple SCMs exist within the SP study reach, including a wet pond SCM, which was monitored during this study, and two additional SCMs, including a bioretention area and a wet pond located just upstream of SP-DS3.

Because of the small size of the SL watershed, the stream reach was very shallow, highly sinuous, and had fine sand and silt substrate. The riparian vegetation in SL was a preserved, mixed hardwood forest, similar to SP. The SL watershed was mitigated by four SCMs: two upstream of our study reach, one wetland within the reach, and one below. The SCM below the reach was a large sedimentation basin, which often backed up water and lead to wetland-like conditions in the riparian areas adjacent to SL-DS3.

\subsection{Sediment and Stream Water Analysis}

Sediment and stream water samples were collected concurrently with denitrification assays to measure sediment organic matter content $(\mathrm{OM})$ and concentrations of $\mathrm{NO}_{3}-\mathrm{N}$. Water samples were filtered in the laboratory with $0.7 \mu \mathrm{m}$ Whatman GF/F glass fiber filters into acid-washed bottles and immediately frozen at $-20{ }^{\circ} \mathrm{C}$. Water samples were analyzed for dissolved $\mathrm{NO}_{3}-\mathrm{N}$ on a Lachat QuikChem 8500 flow injection analyzer (Hach Inc., Loveland, CO, USA) using standard methods [42]. Sediments used in the DNF and DEA assays were oven-dried at $50{ }^{\circ} \mathrm{C}$ for one week and subsequently weighed to obtain dry mass (DM). Sediment organic matter (OM) was obtained through mass loss on ignition by burning dried sediments at $500{ }^{\circ} \mathrm{C}$ for four hours and reweighing post combustion.

\subsection{Denitrification Assays}

From 2011-2014, we measured DNF (actual denitrification) and DEA (potential denitrification) seasonally in stream channel sediments during baseflow conditions. We measured DNF from fall 2011-spring 2012 (three sampling events) to determine the variability of in situ rates based on the existing conditions of the local environment. We measured DEA from summer 2012-spring 2013 (four sampling events) to determine the capacity of the microbial community to denitrify resulting from the long-term conditions that influence the development of the denitrifying community. During the study, a section of the stream draining UP was disturbed for maintenance and repair of stability issues near a road crossing. As such, we collected seasonal data at UP only from summer 2013-winter 2014 (three sampling events). The data are comparable across sites because the three sampling years (2011-2014) were similar in terms of climate and precipitation totals, and land use was stable.

For both assays, reach-integrated sediment samples and stream water were collected at each site. Sediment cores were sampled to a depth of $5 \mathrm{~cm}$ using plexiglass core tubes ( $3.8 \mathrm{~cm}$ in diameter). This depth was selected according to previous studies that have found that this was the most biologically active layer of stream sediments (e.g., Reference [15]). To obtain a rate measurement that was representative of the entire reach, we collected five cores each from two pool habitats and two riffle habitats for a total of 20 cores. These were combined to create a composite sample for each site (i.e., one each at US, DS1, DS2, and DS3). Assays and sediment properties for each site were measured in the laboratory in triplicate. Unfiltered stream water samples were also collected at the 
time of sediment sampling. Water and sediments were kept on ice and immediately brought back to the laboratory where they were stored at $4{ }^{\circ} \mathrm{C}$ and processed within $24 \mathrm{~h}$.

We used the chloramphenicol-amended acetylene-block method on sediment slurries in anoxic microcosms to measure denitrification rates of stream sediments [38,43]. During 2011-2012, sediments were analyzed for DNF using unaltered stream water. DEA was measured in samples collected from 2012-2014 using stream water amended with an additional $5 \mathrm{mg} \cdot \mathrm{L}^{-1} \mathrm{NO}_{3}-\mathrm{N}$ above background concentrations to remove the nitrate limitation but no carbon sources (e.g., glucose) were added.

Triplicate $75 \mathrm{~mL}$ slurries were created with $25 \mathrm{~mL}$ of sediment and $50 \mathrm{~mL}$ of either unfiltered stream water (DNF) or $\mathrm{NO}_{3}-\mathrm{N}$ amended stream water (DEA) in $125 \mathrm{~mL}$ Wheaton glass media bottles. We added chloramphenicol to the soil slurry to reach a concentration of $0.3-0.4 \mathrm{mM}$ (ACROS Organics, Fisher Scientific). Chloramphenicol is an antibiotic that inhibits the production of new enzymes, allowing for denitrification rates measured in bottle assays to be more representative of the denitrification activity at the time of sampling. The bottles were sealed with septa caps and purged with helium to remove oxygen. Immediately following the induction of anoxia, we injected pure acetylene gas into the sealed anoxic bottles through septa caps using a syringe to reach a concentration of $10 \%$ by volume. Acetylene inhibited the conversion of nitrous oxide $\left(\mathrm{N}_{2} \mathrm{O}\right)$ to $\mathrm{N}_{2}$ by blocking the activity of nitrous oxide reductase and allowed us to measure the accumulation of $\mathrm{N}_{2} \mathrm{O}$ to determine denitrification rates.

Slurries were incubated at room temperature $\left(\approx 22{ }^{\circ} \mathrm{C}\right)$ for $4-6 \mathrm{~h}$, and five $500 \mu \mathrm{L}$ gas samples were removed from the bottle headspaces at $45 \mathrm{~min}$ intervals throughout the incubation for the measurement of $\mathrm{N}_{2} \mathrm{O}$ production over time. Bottles were shaken prior to headspace removal to equilibrate $\mathrm{N}_{2} \mathrm{O}$ between the gas and aqueous phases. Gas samples were analyzed immediately by gas chromatography by manually injecting the $500 \mu \mathrm{L}$ sample directly into a Shimadzu GC-2014 (Shimadzu Scientific Instruments, Columbia, MD, USA, 2010) equipped with a $2 \mathrm{~m}$ Porapak Q column and a ${ }^{63} \mathrm{Ni}$ electron capture detector. Concentrations were corrected for $\mathrm{N}_{2} \mathrm{O}$ solubility in the aqueous phase using the temperature-dependent Bunsen coefficient based on ambient laboratory temperature [44]. The linear rate of $\mathrm{N}_{2} \mathrm{O}$ production was used to determine the rate of denitrification within each microcosm. Only time periods representing linear production of $\mathrm{N}_{2} \mathrm{O}$ were used for calculations due to potential interference of bottle effects. DNF and DEA rates were scaled to substratum area sampled $\left(\mathrm{mg}-\mathrm{N} \cdot \mathrm{m}^{-2} \cdot \mathrm{h}^{-1}\right)$ to determine an aerial flux of $\mathrm{N}$ removal in the stream sediments.

\subsection{Statistical Analysis}

We performed all statistical analyses using R version 3.5.1 [45]. To determine how SCMs influenced denitrification processes downstream of the SCM-stream confluence and whether there were differences that corresponded to proximity to the SCM, we first visually compared longitudinal patterns of seasonal DNF and DEA, and then performed a one-way analysis of variance (ANOVA) of DNF and DEA within each stream across seasons with location (US, DS1, DS2, DS3) as a fixed factor. We evaluated differences in DNF and DEA among sites with pairwise comparisons using Tukey's honest significant difference (HSD) test with a 95\% confidence interval. Because the study streams were located in different watersheds with variable catchment and local environmental characteristics, we used simple linear regressions to analyze the relationship of DNF and DEA to hypothesized causal variables across streams. DNF rates were regressed with water column $\mathrm{NO}_{3}-\mathrm{N}$ concentrations and $\mathrm{OM}$, and DEA rates were regressed with sediment $\mathrm{OM}$. All values were log-transformed prior to analysis to achieve Gaussian distribution and normalize residuals.

To determine how the influence of the SCM on DNF and DEA across streams varied as a function of development and SCM type, we normalized the difference in DNF and DEA between DS1 and US. This accounts for varying environmental conditions at each stream and isolate the influence of the 
SCMs on denitrification. This factor was calculated as the percent change in DNF and DEA from upstream to downstream of the SCM and denoted as $\triangle \mathrm{DNF}$ and $\triangle \mathrm{DEA}$, respectively:

$$
\begin{aligned}
\Delta \mathrm{DNF} & =\frac{\mathrm{DNF}_{\mathrm{DS} 1}-\mathrm{DNF}_{\mathrm{US}}}{\mathrm{DNF}_{\mathrm{US}}} \\
\Delta \mathrm{DEA} & =\frac{\mathrm{DEA}_{\mathrm{DS} 1}-\mathrm{DEA}_{\mathrm{US}}}{\mathrm{DEA}_{\mathrm{US}}}
\end{aligned}
$$

where DEA $A_{D S 1}$ and DEA $A_{U S}$ are the measured DNF and DEA rates at the DS1 (i.e., immediate downstream of the stream-SCM confluence) and US monitoring locations (i.e., upstream of the stream-SCM confluence) at a given site, respectively. We used a two-factor ANOVA to test the effects of site and season on $\triangle \mathrm{DEA}$ with site and season as fixed factors and evaluated these differences with pairwise comparisons using Tukey's HSD test with a 95\% confidence interval.

\section{Results}

\subsection{Denitrification Processes Downstream of the Stream-SCM Confluence}

We compared DNF and DEA longitudinally by site and compared these patterns to SCM outflow locations (Figure 3) and other stream characteristics that could affect flow patterns and/or carbon storage. Longitudinal DNF patterns showed no consistent patterns within a single site and were variable across seasons (Figure 3a-d). However, interesting patterns emerged that were unique to each site corresponding to inputs of additional SCMs and/or development of instream features (e.g., beaver dams). DNF pooled across seasons at SP were significantly higher at SP-DS3 (downstream of the input of the additional bioretention pond) compared to SP-US and most evident during summer and spring (ANOVA, $p=0.031$ ). We also observed a significant increase in DNF rates at SL-DS3 compared to SL-US during the fall (ANOVA, $p=0.046$ ), concurrent with seasonal backwater effects from a downstream sedimentation pond.

DNF rates were highly correlated with in-stream $\mathrm{NO}_{3}-\mathrm{N}$ concentrations (Figure $4 \mathrm{a}, \mathrm{r}^{2}=0.762$, $p<0.0001$ ) with DNF rates increasing with increased stream water $\mathrm{NO}_{3}-\mathrm{N}$ concentrations. Seasonal DNF rates were highly variable, ranging from $0-6.60 \mathrm{mg}-\mathrm{N} \cdot \mathrm{m}^{-2} \cdot \mathrm{h}^{-1}$, with low rates in the fall and high rates during spring and summer (Table 3 and Table S1).

The highest DNF rates were observed at UL when pooled across all monitoring locations and seasons $\left(p<0.0001\right.$, ANOVA). In-stream $\mathrm{NO}_{3}-\mathrm{N}$ concentrations during baseflow ranged from $<0.002-0.540 \mathrm{mg} \cdot \mathrm{L}^{-1}$ and followed similar patterns to DNF rates. The lowest values occurred in the fall for all sites except $\mathrm{SL}$, where values were lowest in the winter when $\mathrm{NO}_{3}-\mathrm{N}$ concentrations were below detection, and the highest $\mathrm{NO}_{3}-\mathrm{N}$ concentrations were observed at $\mathrm{UL}$ across all seasons $(p<0.001$, ANOVA). DNF rates were negatively correlated with sediment OM; however, this explained a relatively low proportion of the variability (Figure $4 b, r^{2}=0.180, p=0.0026$ ).

Because DNF rates were highly correlated with in-stream $\mathrm{NO}_{3}-\mathrm{N}$ concentrations, patterns were masked by $\mathrm{NO}_{3}-\mathrm{N}$ availability. To observe trends in denitrification across sites, we measured DEA seasonally from 2012-2014 (Table 2 and Table S2). DEA varied by stream with significantly higher rates at UP and SL $\left(40.86 \pm 29.22 \mathrm{mg}-\mathrm{N} \cdot \mathrm{m}^{-2} \cdot \mathrm{h}^{-1}\right.$ and $33.43 \pm 16.71 \mathrm{mg}-\mathrm{N} \cdot \mathrm{m}^{-2} \cdot \mathrm{h}^{-1}$, respectively) compared to UL and SP $\left(13.97 \pm 11.35 \mathrm{mg}-\mathrm{N} \cdot \mathrm{m}^{-2} \cdot \mathrm{h}^{-1}\right.$ and $15.92 \pm 6.70 \mathrm{mg}-\mathrm{N} \cdot \mathrm{m}^{-2} \cdot \mathrm{h}^{-1}$ at SP, respectively) (ANOVA, $p<0.01$ ). In addition, DEA rates were positively correlated with sediment OM (Figure 5, $\left.\mathrm{r}^{2}=0.187, p=0.0014\right)$. 
DNF

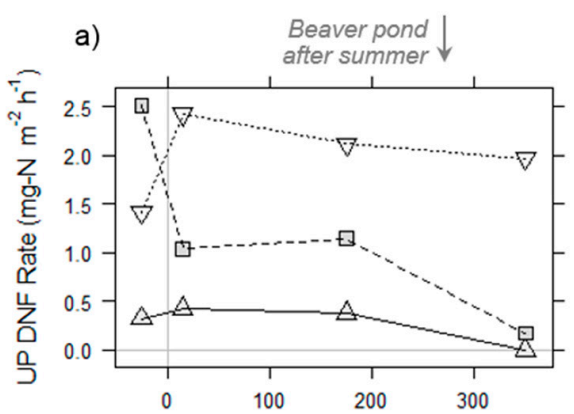

b)

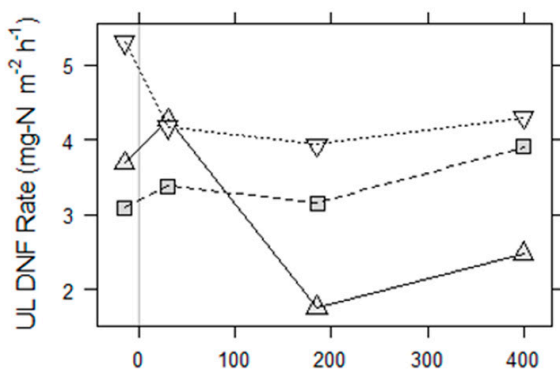

c)

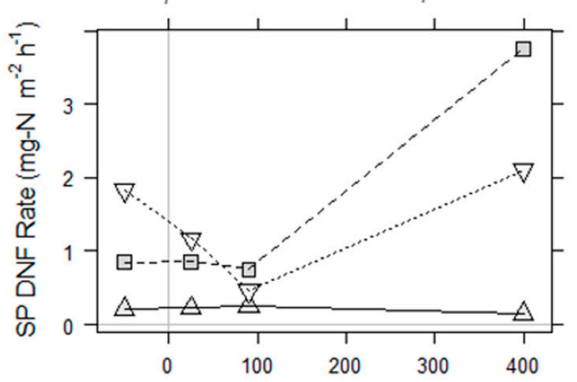

d)

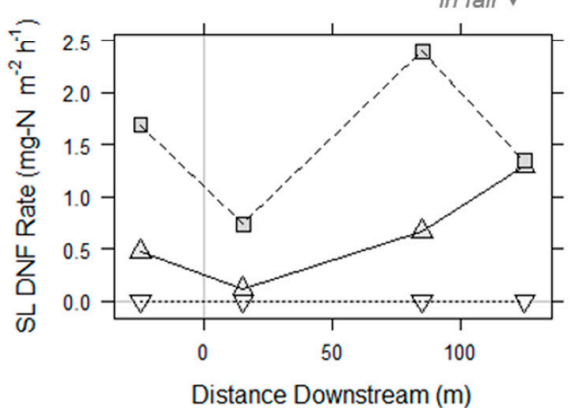

DEA

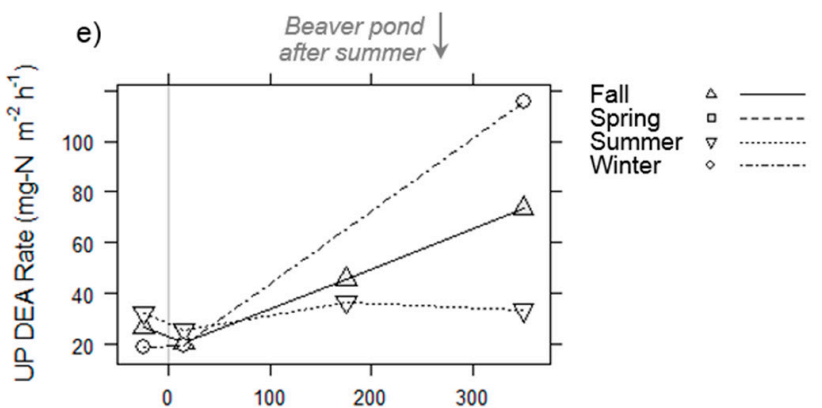

f)
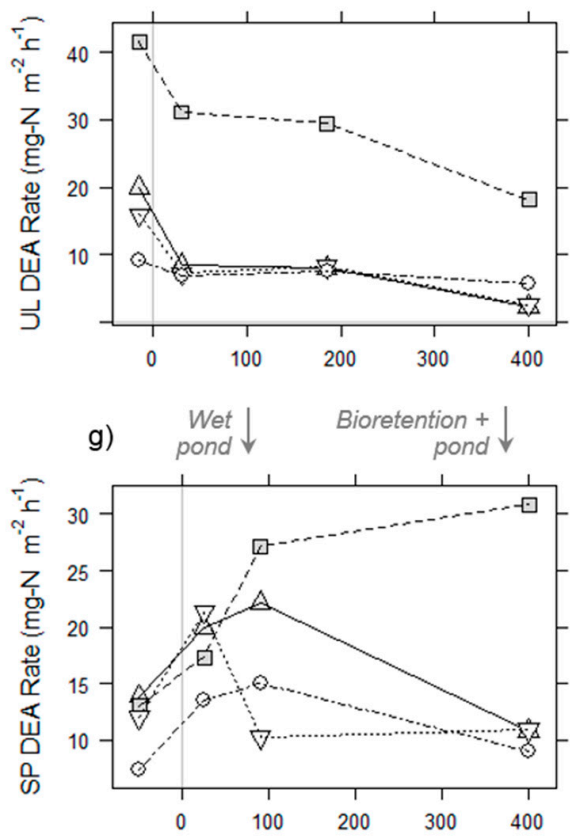

h)

Backwater

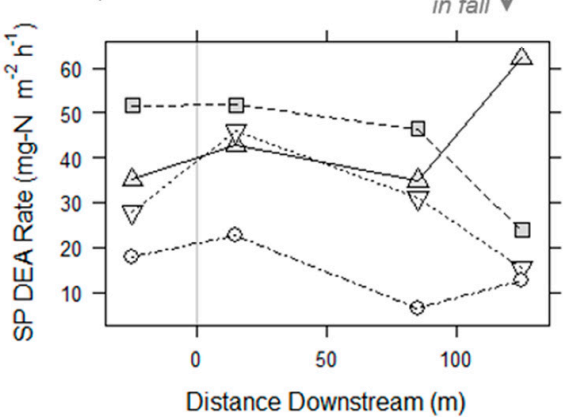

Figure 3. Seasonal actual denitrification rates (DNF; a-d) rates and potential denitrification rates (DEA; e-h) along the longitudinal gradient from upstream to downstream at urban pond (UP), urban wetland (UL), suburban pond (SP), and suburban wetland (SL). The location of the stormwater control measure (SCM) is indicated by the $0 \mathrm{~m}$ distance and its location is represented by the gray line. Sites upstream (US) of the SCM are designated as negative distances, and the three downstream sites (DS1, DS2, and DS3) are indicated by positive distances. Points represent the average rates at each site during each season as determined through triplicate laboratory measurements. Error bars are not shown in order to increase figure clarity due to series overlap. Results from Tukey's HSD post hoc test are shown in Tables 2 and 3. 
Table 2. Seasonal DEA rates $( \pm S D)$ at each location within the four study sites. Superscript letters denote groups according to probability of mean differences (ANOVA with Tukey's HSD post hoc test, $\alpha=0.05$, performed on log-transformed data). Measurements with the same letter are not significantly different.

\begin{tabular}{|c|c|c|c|c|c|}
\hline \multirow{2}{*}{ Site } & \multirow{2}{*}{ Monitoring Location } & \multicolumn{4}{|c|}{ Seasonal DEA Rates $\left(\mathrm{mg}-\mathrm{N} \cdot \mathrm{m}^{-2} \cdot \mathrm{h}^{-1}\right)$} \\
\hline & & Summer & Fall & Winter & Spring \\
\hline \multirow[t]{4}{*}{$\mathrm{UP}^{1}$} & US & $32.54(2.60)^{\mathrm{cd}}$ & $26.71(1.37) \mathrm{de}$ & $19.19(6.67)^{e}$ & no data \\
\hline & DS1 & $25.98(0.91)$ de & $20.63(1.05)^{\mathrm{e}}$ & $19.51(2.94)^{\mathrm{e}}$ & no data \\
\hline & DS2 & $36.84(3.30) \mathrm{cd}$ & $45.56(11.06)^{\mathrm{c}}$ & no data & no data \\
\hline & DS3 & $33.45(1.94)^{\mathrm{cd}}$ & $73.68(10.29)^{b}$ & $115.33(16.71)^{\mathrm{a}}$ & no data \\
\hline \multirow[t]{4}{*}{$\mathrm{UL}^{2}$} & US & $15.92(1.04)^{c}$ & $19.88(1.30)^{b c}$ & $9.24(1.50)^{d}$ & $41.59(3.58)^{\mathrm{a}}$ \\
\hline & DS1 & $7.24(0.54)$ de & $8.49(0.81)^{d}$ & $6.80(0.07)$ de & $31.12(3.60)^{\mathrm{a}}$ \\
\hline & DS2 & $8.25(1.19)^{c}$ & $7.99(1.24)$ de & $7.56(0.78)$ de & $29.47(1.45)^{a b}$ \\
\hline & DS3 & $2.62(0.38)^{f}$ & $2.35(0.66)^{f}$ & $5.79(1.78)^{\mathrm{e}}$ & $18.14(3.40)^{b c}$ \\
\hline \multirow[t]{4}{*}{$\mathrm{SP}^{2}$} & US & $12.02(1.34)^{\mathrm{fgh}}$ & $13.86(0.47)$ defg & $7.41(0.73)^{\mathrm{i}}$ & $13.00(0.94)^{\mathrm{efg}}$ \\
\hline & DS1 & $21.37(3.17) b c$ & $19.99(1.31)^{b c d}$ & $13.57(1.85)$ efg & $17.30(0.79)$ cde \\
\hline & DS2 & $10.23(1.27)$ ghi & $22.18(1.83) \mathrm{bcd}$ & $15.03(2.23)$ def & $27.12(2.95)^{a b}$ \\
\hline & DS3 & $10.96(1.27)^{\mathrm{fgh}}$ & $10.81(1.00)^{\mathrm{fgh}}$ & $8.97(1.75)$ hi & $30.85(2.40)^{\mathrm{a}}$ \\
\hline \multirow[t]{4}{*}{$\mathrm{SL}^{2}$} & US & $27.89(2.87)^{\text {ef }}$ & $35.06(0.70)^{d}$ & $17.74(0.32)^{h}$ & $51.63(1.38)^{a b}$ \\
\hline & DS1 & $45.91(1.94)^{\mathrm{C}}$ & $42.82(0.78)^{\mathrm{c}}$ & $22.66(1.96)^{g}$ & $51.79(1.65) \mathrm{bc}$ \\
\hline & DS2 & $31.03(1.93) \mathrm{de}$ & $34.96(1.21)^{d}$ & $6.52(0.49)^{j}$ & $46.39(11.95)^{\mathrm{c}}$ \\
\hline & DS3 & $15.42(1.82)^{h}$ & $62.12(1.73)^{a}$ & $12.46(0.88)^{\mathrm{i}}$ & $23.81(0.71) \mathrm{fg}$ \\
\hline
\end{tabular}

${ }^{1}$ DEA measured in 2013-2014; ${ }^{2}$ DEA measured in 2012-2013. No data were collected for UP during periods where site or locations were inaccessible due to construction activity.

Table 3. Seasonal DNF rates \pm standard deviations (SDs) at each location within the four study sites. Superscript letters denote groups according to probability of mean differences (ANOVA with Tukey's HSD post hoc test, $\alpha=0.05$, performed on log-transformed data). Measurements with the same letter are not significantly different.

\begin{tabular}{|c|c|c|c|c|}
\hline \multirow{2}{*}{ Site } & \multirow{2}{*}{ Monitoring Location } & \multicolumn{3}{|c|}{ Seasonal DNF Rates $\left(\mathrm{mg}-\mathrm{N} \cdot \mathrm{m}^{-2} \cdot \mathrm{h}^{-1}\right)$} \\
\hline & & Fall & Winter & Spring \\
\hline \multirow[t]{4}{*}{ UP } & US & $1.74(2.45)$ de & $1.42(0.34) \mathrm{bc}$ & $2.52(0.22)^{a}$ \\
\hline & DS1 & $0.42(0.29)^{d}$ & $2.42(0.23)^{\mathrm{a}}$ & $1.04(0.24)^{\mathrm{c}}$ \\
\hline & DS2 & $0.37(0.04)^{\mathrm{d}}$ & $2.12(0.34)^{a b}$ & $1.15(0.28)^{\mathrm{c}}$ \\
\hline & DS3 & $0(0) \mathrm{e}^{\mathrm{e}}$ & $1.97(0.3)^{\mathrm{ab}}$ & $0.17(0.001)^{\mathrm{de}}$ \\
\hline \multirow[t]{4}{*}{$\mathrm{UL}$} & US & $3.69(0.34)^{\mathrm{ab}}$ & $5.3(1.41)^{\mathrm{a}}$ & $3.09(0.41)^{a b c}$ \\
\hline & DS1 & $4.27(0.78)^{a b}$ & $4.17(0.51)^{a b}$ & $3.38(0.46)^{a b}$ \\
\hline & DS2 & $1.76(0.38)^{\mathrm{c}}$ & $3.93(0.36)^{a b}$ & $3.49(0.6)^{a b c}$ \\
\hline & DS3 & $2.48(0.81)^{b c}$ & $4.3(1.1)^{\mathrm{ab}}$ & $3.91(0.22)^{a b}$ \\
\hline \multirow[t]{4}{*}{$\mathrm{SP}$} & US & $0.21(0.11)^{f}$ & $1.83(0.89)^{b}$ & $0.84(0.1)^{\mathrm{cd}}$ \\
\hline & DS1 & $0.22(0.04)$ ef & $1.17(0.21)^{b c}$ & $0.86(0.33)^{\mathrm{cd}}$ \\
\hline & DS2 & $0.25(0.03)$ ef & $0.47(0.11)$ def & $0.75(0.13)$ cde \\
\hline & DS3 & $0.15(0.03)^{\mathrm{f}}$ & $2.1(0.32)^{b}$ & $3.76(0.16)^{a}$ \\
\hline \multirow[t]{4}{*}{$\mathrm{SL}$} & US & $0.47(0.1) \mathrm{de}$ & $0(0)^{f}$ & $1.69(0.48)^{a b}$ \\
\hline & DS1 & $0.12(0.01)$ ef & $0(0)^{\mathrm{f}}$ & $1.22(0.87)^{\mathrm{cd}}$ \\
\hline & DS2 & $0.67(0.1)^{\mathrm{d}}$ & $0(0)^{\mathrm{f}}$ & $2.39(0.32)^{a}$ \\
\hline & DS3 & $1.03(0.45)^{b c}$ & $0(0)^{\mathrm{f}}$ & $1.34(0.37)^{b c}$ \\
\hline
\end{tabular}

Longitudinal DEA patterns were generally consistent across seasons within a single site with the exception of SP, which demonstrated greater variability (Table 2, Figure 3e-h); however, pooled rates across seasons were not significantly different among locations within any stream (ANOVA with Tukey's 
HSD post hoc test, $\alpha=0.05)$. DEA rates decreased from UP-US to UP-DS1 across seasons and increased an order of magnitude from August 2013 (summer) to March 2014 (winter) at UP-DS3, which coincided with the development of an in-line beaver pond upstream of the sampling location that formed prior to sampling in Fall 2013 (Figure 3a). At SP, DEA rates consistently increased from SP-US to SP-DS2 across seasons, with the exception of summer (SP-DS2), coinciding with addition of impervious area that was entirely mitigated by a wet pond (Figure 3f). UL had no additional SCM inputs to the stream below the SCM-stream confluence, and DEA rates were relatively similar longitudinally downstream with highest rates observed during the spring (Figure 3g). Finally, DEA rates at SL were variable across seasons, but showed an increase at SL-DS3 during fall when the site experience prolonged inundation resulting from backwater effects from a downstream sedimentation pond (Figure $3 \mathrm{~h}$ ).

a)

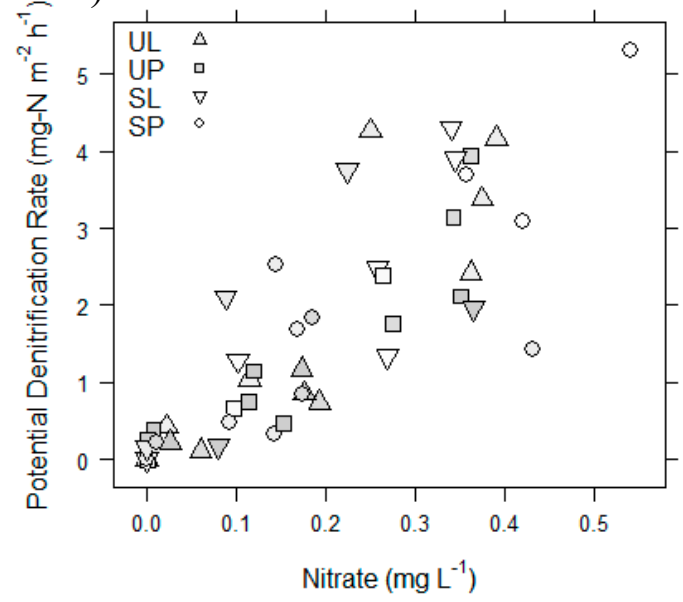

b)

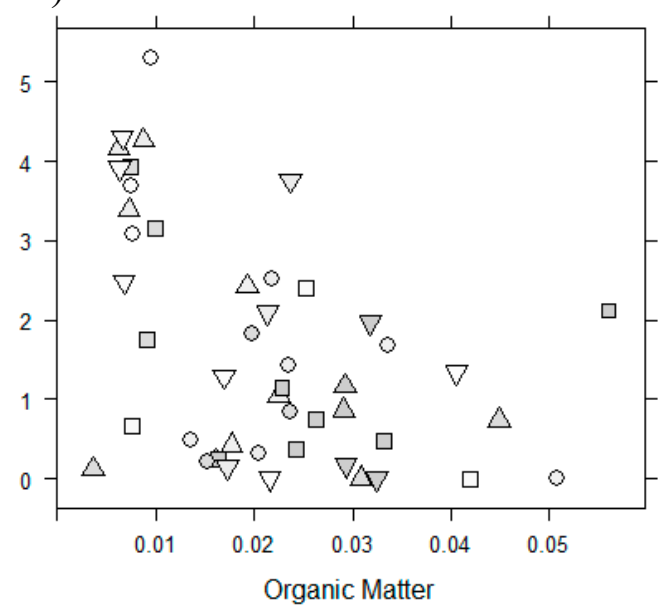

Figure 4. Actual denitrification rates (DNF) with: (a) water column nitrate concentrations, and (b) sediment organic matter (OM) during 2011-2012 for all streams and locations. Actual values are shown, statistics performed on log-transformed data. DNF was positively correlated with $\mathrm{NO}_{3}-\mathrm{N}$ concentrations $\left(\mathrm{r}^{2}=0.7623, p<0.0001\right)$ and negatively correlated with $\mathrm{OM}\left(\mathrm{r}^{2}=0.180, p<0.005\right)$.

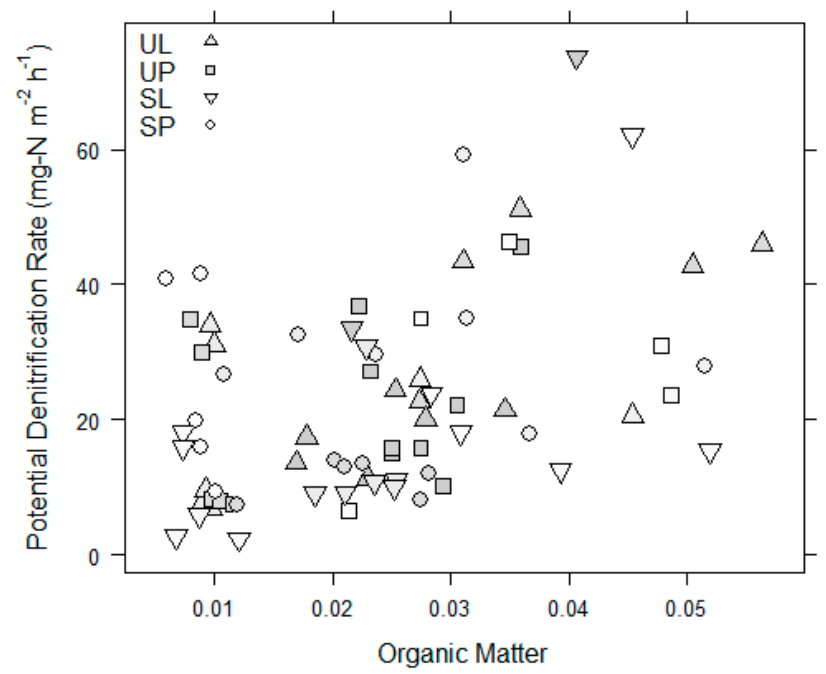

Figure 5. Potential denitrification rates (DEA) and sediment organic matter (OM) during 2013-2014 for all streams and locations. Actual values are shown with statistics performed on log-transformed data. DEA was positively correlated with OM. The relationship between log-transformed DEA and log-transformed OM was significant $\left(\mathrm{r}^{2}=0.187, p<0.0005\right)$. 


\subsection{SCM Influence on Stream Denitrification across Development Types}

The difference in DNF and DEA upstream and downstream of the SCM confluence ( $\triangle \mathrm{DNF}$ and $\triangle \mathrm{DEA}$, respectively) was computed to normalize for variable environmental conditions across sites and isolate the effects of the SCM on stream denitrification processes. $\triangle \mathrm{DNF}$ showed no significant differences across sites or seasons (Figure 6a, ANOVA). $\triangle \mathrm{DEA}$, however, showed significantly different patterns across sites (Figure 6 b). Urban sites (UP, UL) showed a pattern of significantly higher rates upstream across seasons, resulting in $\triangle \mathrm{DEA}<1(p<0.01$, ANOVA), while suburban sites (SP, SL) showed the opposite trend with higher rates downstream, resulting in $\triangle \mathrm{DEA}>1(p<0.01$, ANOVA). We used a two-factor ANOVA to test the effects of site and season on $\triangle D E A$. Season had no significant effect on $\triangle D E A$, but $\triangle D E A$ showed significant differences among sites. Post hoc analysis using Tukey's HSD showed that there were no differences in $\triangle D E A$ between the urban sites or between the suburban sites; however, SP (lowest imperviousness) was significantly higher than UL $(p=0.001)$ and UP $(p=0.018)$ across seasons, and UL (highest imperviousness) was significantly lower than SP ( $p=0.001)$ and SL $(p=0.013)$. Mean values of $\triangle$ DEA decreased with increasing levels of imperviousness among the four sites in this study. No consistent patterns in $\triangle \mathrm{DNF}$ or $\triangle \mathrm{DEA}$ were observed with different SCM type (pond or wetland).

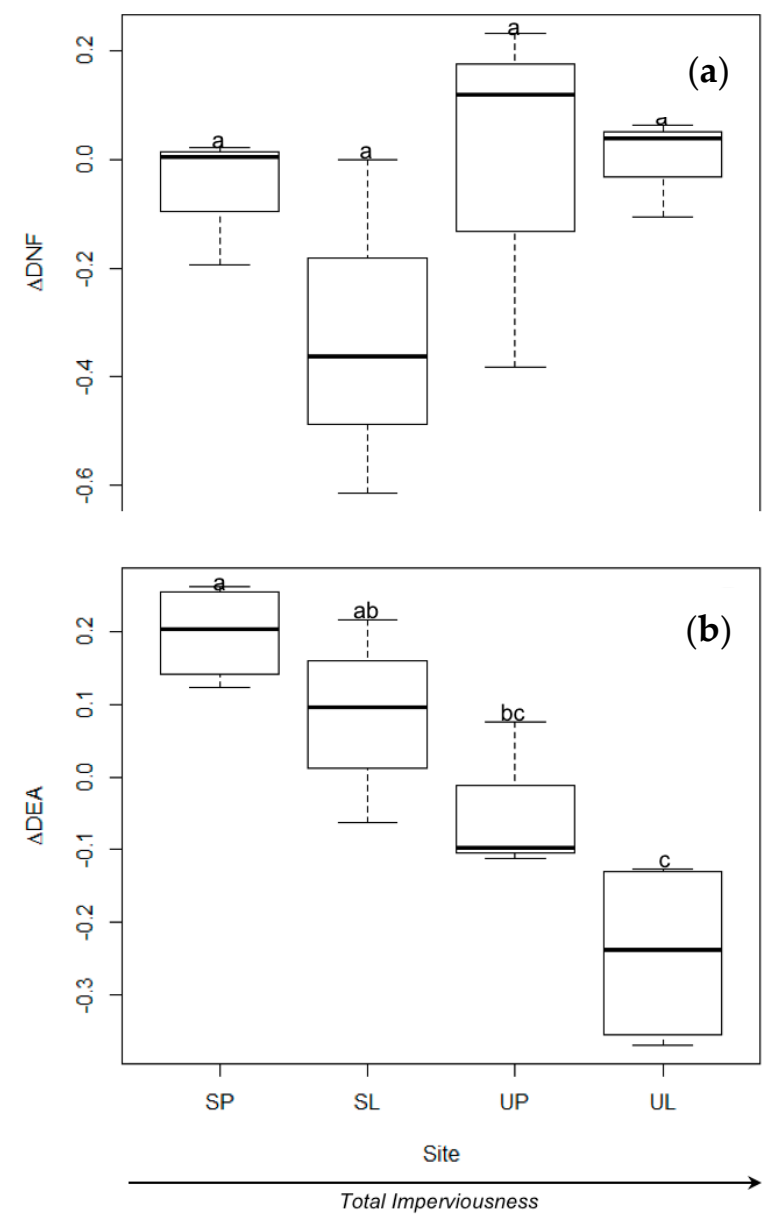

Figure 6. Boxplot with Tukey's HSD post hoc test of (a) $\triangle \mathrm{DNF}$ and (b) $\triangle \mathrm{DEA}$ among sites across seasons. Box and whiskers show the range in $\triangle \mathrm{DEA}$ at each site across all seasons. Letters denote groups according to probability of mean differences (ANOVA with Tukey's HSD post hoc test, $\alpha=0.05$ ). Measurements with the same letter are not significantly different. No significant differences in $\triangle \mathrm{DNF}$ existed between locations across seasons. Levels of total imperviousness in the DS1 watersheds increase from left to right along the $x$-axis. $\triangle \mathrm{DNF}$ and $\triangle \mathrm{DEA}$ is the percent change in DNF and DEA, respectively, from upstream to downstream of the SCM and is calculated using Equations (1) and (2) in the text. 


\section{Discussion}

\subsection{Influence of SCM Inputs on Instream Denitrification}

While considerable monitoring of SCM inflow and outflow has shown reductions in sediment and dissolved nutrient concentrations at the individual SCM scale [46,47], the net effect of altered stream chemistry, carbon subsidies, and flow regimes on stream ecosystems receiving inputs of treated stormwater runoff remains largely unexplored. Through a multi-year study of denitrification rates, while we observed rates that were consistent with those measured in urban streams globally [48], we found that in-stream denitrification was often enhanced immediately downstream of SCM-stream confluences and naturally-developed in-stream features such as beaver ponds and backwater effects from downstream ponds. This was particularly evident in the suburban watersheds where potential DEA was higher downstream of SCM-stream confluences, which may be due to a combination of changing water chemistry via altered inputs to the stream [22,49] and geomorphological differences among the sites in terms of substrate type [21,50].

The convergence of complementary reactants at the confluence of hydrologic flowpaths has been documented to result in high rates of biogeochemical processes [29,51]. Studies of natural and constructed wetlands show that coupled processing of $\mathrm{N}$ and $\mathrm{C}$ affects dissolved nutrient dynamics outflows to surface waters downstream $[52,53]$ and this can alter the input of subsidies to aquatic communities. Headwater wetlands have been shown to transform inflows of inorganic $\mathrm{N}$ to outflows of organic N, thereby increasing the net export of dissolved organic carbon (DOC) and dissolved organic nitrogen (DON) [54]. SCMs, in particular, have also shown $\mathrm{N}$ removal and transformation $[55,56]$. The confluence between the stream and DOC- and DON-rich outflows from SCMs designed to mimic natural systems may provide conditions that foster microbial growth due to the input of elevated dissolved nutrient concentrations. A parallel study at SP showed that outflow from the pond accounted for a percentage (11-43\%) of total streamflow larger than its drainage area on the recession limb of a storm hydrograph [20]. This addition of SCM outflow water resulted in an increase of both $\mathrm{NO}_{3}-\mathrm{N}$ and DOC concentrations downstream of the confluence late in the hydrograph [49].

Urban streams tend to experience flashy storm hydrographs as a result of increased impervious surface cover in the catchment. This large increase in discharge over a short time period reduces channel stability $[57,58]$ and consequently may inhibit the development and persistence of biologically-relevant sediment characteristics and structures such as organic debris dams and stable sediment habitats that foster microbial growth and activity [59]. By attenuating peak flows, SCMs provide greater channel protection by reducing the magnitude of discharge during high-flow events and decreasing physical disturbance of stream sediments, which has the potential to enhance microbial habitat quality. Previous modeling studies have demonstrated that SCMs can increase geomorphic stability and reduce stream erosion potential, particularly for coarse stream bed material $[21,60]$. While we did not directly measure changes in bed material or erosion rates, we observed increases in denitrification downstream of areas with increased channel residence time (e.g., beaver ponds), which suggests that slower velocities may also enhance depositional processes, particularly of finer sediments that have been shown to have higher rates of denitrification and metabolism [15,16,61]. We also observed elevated rates along the stream reach and hypothesize that these may be influenced by inputs of additional SCMs along the stream reach (e.g., SP), and/or increased water residence times within the channel because of backwater effects and/or beaver wetland creation (e.g., SL and UP, respectively).

\subsection{Environmental Controls}

Controls on denitrification followed patterns well-established in many other natural and human-influenced streams including resource availability and hydrologic conditions $[16,17,48,61]$. By using two complementary methods to quantify denitrification rates, we were able to assess the drivers of variability across a range of environmental conditions. Specifically, we described differences in denitrification related to proximal controls of short-term microbial response $\left(\mathrm{NO}_{3}-\mathrm{N}\right.$ and organic 
matter) and environmental factors impacting longer term activity. As expected, actual denitrification rates were highly correlated with in-stream $\mathrm{NO}_{3}-\mathrm{N}$ concentrations [61,62]; however, were only weakly and negatively correlated with sediment organic matter content [63,64]. Interestingly, organic matter was only important when $\mathrm{NO}_{3}-\mathrm{N}$ limitation was removed as seen by positive correlations with DEA rates. This suggests two things: first, the urban streams in this study were not saturated with respect to $\mathrm{NO}_{3}-\mathrm{N}$ and have the capacity for higher rates of denitrification if they are stressed by higher concentrations in the stream; and second, enriched quantity and quality of $\mathrm{C}$ subsidies to these microbial communities may be a critically important control on rates under higher $\mathrm{NO}_{3}-\mathrm{N}$ conditions. In addition to $\mathrm{C}$ in SCM outflow, preserving forested riparian zones in urban environments may help achieve water quality goals by enhancing $\mathrm{N}$ removal via denitrification; woody debris in streams increases flowpath heterogeneity and residence times, and leaf litter inputs provide long-term source of $\mathrm{C}$ to sediment microbes.

\subsection{Watershed Scale Controls}

Substantial changes to both resource availability and hydraulic conditions have the potential to occur at the SCM-stream confluence. Here, we propose that these changes, which have been shown to affect denitrification rates, may be controlled by watershed characteristics. A one-way ANOVA of $\triangle \mathrm{DEA}$ with site as fixed factors showed different responses in DEA below the SCM-stream confluence across sites. These results showed a pattern of decreasing potential denitrification rates (normalized to upstream rates) as imperviousness increased, which suggests that the relative influence of each SCM may be diminished with greater impervious cover. At higher levels of imperviousness (e.g., UL), we consistently observed higher denitrification rates $(\triangle \mathrm{DNF})$ upstream of the SCM confluence across all seasons, suggesting that the SCM was not able to mitigate impacts of increased flow from the impervious surfaces draining to the stream at that point. At lower levels of imperviousness (e.g., SP), the highest values of $\triangle \mathrm{DEA}$ were consistently observed across seasons, suggesting that the SCM may provide a mechanism for increased DEA in the stream. The suburban and urban sites also demonstrated a separation: the suburban sites yielded $\triangle \mathrm{DEA}$ values greater than 1 , and the urban sites generally showed ratio values less than 1 .

These results suggest that SCMs in watersheds with high imperviousness have limited capacity to mitigate effect of urbanization on denitrification in receiving streams and we suggest that this is due to high runoff volumes from the impervious surfaces. In these cases, the SCMs may have a reduced capacity to attenuate peak flows and mitigate the scouring effects on the receiving streams during storm events because of the small relative input of SCM discharge compared to upstream hydrologic inputs. In a study of the effects of SCMs on hydrology that included the four sites examined here, Bell et al. [35] showed that impervious surface coverage had the greatest influence on peak discharge and runoff behavior rather than other metrics that quantify SCM mitigation, particularly at the event scale. Erosional processes resulting from high storm discharge is reflected in sediment processes [11], and sediment transport may inhibit microbial processes by disturbing benthic resource retention and community growth. Therefore, downstream habitats may be less stable for microbial activity when watershed imperviousness is high.

\section{Conclusions}

Headwater streams are demonstrated hot spots of nutrient removal on the landscape; however, degradation of streams through urbanization reduces their effectiveness $[8,65,66]$. SCM implementation at the small watershed scale has the potential to both directly enhance retention and removal within the watershed and indirectly increase these functions in the stream network. SCMs function as a means of disconnecting impervious runoff from direct drainage to streams by retaining stormwater runoff, thereby attenuating many of the degrading effects of urban runoff. Our results show that SCMs integrated into the watershed have the potential to create cascading positive effects on in-stream nutrient processing and thereby improve water quality. In watersheds with low levels of 
imperviousness, we observed increasing denitrification rates downstream of the confluence of SCM outflow and in-line ponds. This pattern may be due to greater microbial community establishment resulting from elevated concentrations of subsidies and resources provided by pond and wetland outflows in addition to stabilization of the benthic habitat by lower peak discharge. However, the degree of influence likely depends on the level of urbanization within the watershed in that these effects were found to be significant only in watersheds with low imperviousness. While further work that spans a continuum of urbanization will enhance our understanding of the interactions between land use and SCM type and location (e.g., distributed versus centralized), it is apparent that SCMs can greatly influence receiving stream sediment processes and thereby downstream water quality.

Supplementary Materials: The following are available online at http:/ / www.mdpi.com/2073-4441/10/11/1582/ s1, Table S1: Average denitrification (DNF) rates $( \pm S D)$ and average nitrate $\left(\mathrm{NO}_{3}-\mathrm{N}\right)$ concentrations from triplicate laboratory measurements for each location within the four study sites during the 2011-2012 sampling period. Table S2: Average potential denitrification (DEA) rates $( \pm S D)$ and average sediment organic matter (OM) content (\%) from triplicate laboratory measurements for each location within the four study sites during the 2012-2014 sampling period.

Author Contributions: Conceptualization, E.N.R., S.K.M., C.D.B., and S.M.C.; Formal analysis, E.N.R. and S.K.M.; Methodology, E.N.R. and C.D.B.; Writing—original draft, E.N.R.; Writing-review and editing, S.K.M., C.D.B., and S.M.C.

Funding: This research was funded by a grant from the National Science Foundation, grant number CBET-1034043. The authors also acknowledge support from USDA/NIFA S-1063.

Acknowledgments: We would like to acknowledge the contributions of Anne Jefferson to experimental design. Brittney Marvel and Mackenzie Osypian for all their help with sample collection, and Rachel Scarlett for chemistry data analysis. Additionally, we would like to thank Charlotte-Mecklenburg Stormwater Services for suggesting sampling locations and facilitating their access. Finally, we are appreciative of the access to analytical equipment provided by The University of North Carolina at Charlotte, Purdue University, Portland State University, and the Colorado School of Mines.

Conflicts of Interest: The authors declare no conflict of interest.

\section{References}

1. Paul, M.J.; Meyer, J.L. Streams in the Urban Landscape. Annu. Rev. Ecol. Syst. 2001, 32, 333-365. [CrossRef]

2. Fletcher, T.D.; Andrieu, H.; Hamel, P. Understanding, management and modelling of urban hydrology and its consequences for receiving waters: A state of the art. Adv. Water Resour. 2013, 51. [CrossRef]

3. Jefferson, A.J.; Bhaskar, A.S.; Hopkins, K.G.; Fanelli, R.; Avellaneda, P.M.; McMillan, S.K. Stormwater management network effectiveness and implications for urban watershed function: A critical review. Hydrol. Process. 2017, 31. [CrossRef]

4. Roy, A.H.; Rosemond, A.D.; Paul, M.J.; Leigh, D.S.; Wallace, J.B. Stream macroinvertebrate response to catchment urbanisation (Georgia, USA). Freshw. Biol. 2003, 48, 329-346. [CrossRef]

5. O'Driscoll, M.; Clinton, S.; Jefferson, A.; Manda, A.; McMillan, S. Review: Urbanization effects on watershed hydrology and in-stream processes in the southern United States. Water 2010, 2, 605-648. [CrossRef]

6. United States Environmental Protection Agency. The Quality of Our Nation's Waters; EPA 841-S-00-001; Office of Water: Washington, DC, USA, 2000.

7. Hatt, B.E.; Fletcher, T.D.; Walsh, C.J.; Taylor, S.L. The influence of urban density and drainage infrastructure on the concentrations and loads of pollutants in small streams. Environ. Manag. 2004. [CrossRef] [PubMed]

8. Walsh, C.J.; Roy, A.H.; Feminella, J.W.; Cottingham, P.D.; Groffman, P.M.; Morgan, R.P.; Ii, R.P.M. The urban stream syndrome: Current knowledge and the search for a cure. J. N. Am. Benthol. Soc. 2005, 24, 706-723. [CrossRef]

9. Reisinger, A.J.; Tank, J.L.; Hoellein, T.J.; Hall, R.O. Sediment, water column, and open-channel denitrification in rivers measured using membrane-inlet mass spectrometry. J. Geophys. Res. G Biogeosci. 2016, 121. [CrossRef]

10. United States Environmental Protection Agency. National Rivers and Streams Assessment 2008-2009: A Collaborative Survey; EPA/841/R-16/007; Office of Water and Office of Research and Development: Washington, DC, USA, 2016. 
11. Booth, D.B.; Jackson, C.R. Urbanization of aquatic systems: Degradation thresholds, stormwater detection, and the limits of mitigation. J. Am. Water Resour. Assoc. 1997, 33, 1077-1090. [CrossRef]

12. Perryman, S.E.; Rees, G.N.; Walsh, C.J.; Grace, M.R. Urban Stormwater Runoff Drives Denitrifying Community Composition Through Changes in Sediment Texture and Carbon Content. Microb. Ecol. 2011. [CrossRef] [PubMed]

13. Kemp, M.J.; Dodds, W.K. Comparisons of nitrification and denitrification in prairie and agriculturally influenced streams. Ecol. Appl. 2002, 12, 998-1009. [CrossRef]

14. Seitzinger, S.P. Denitrification in freshwater and coastal marine ecosystems: Ecological and geochemical significance. Limnol. Oceanogr. 1988, 33, 702-724. [CrossRef]

15. Inwood, S.E.; Tank, J.L.; Bernot, M.J. Factors controlling sediment denitrification in midwestern streams of varying land use. Microb. Ecol. 2007, 53, 247-258. [CrossRef] [PubMed]

16. Groffman, P.M.; Dorsey, A.M.; Mayer, P.M. N processing within geomorphic structures in urban streams. J. N. Am. Benthol. Soc. 2005, 24, 613-625. [CrossRef]

17. Harrison, M.D.; Groffman, P.M.; Mayer, P.M.; Kaushal, S.S. Microbial biomass and activity in geomorphic features in forested and urban restored and degraded streams. Ecol. Eng. 2012, 38, 1-10. [CrossRef]

18. National Research Council. Urban Stormwater Management in the United States; National Research Council: Washington, DC, USA, 2009; ISBN 978-0-309-12539-0.

19. Walsh, C.J.; Fletcher, T.D.; Ladson, A.R. Stream restoration in urban catchments through redesigning stormwater systems: Looking to the catchment to save the stream. J. N. Am. Benthol. Soc. 2005, 24, 690-705. [CrossRef]

20. Jefferson, A.J.; Bell, C.D.; Clinton, S.M.; McMillan, S.K. Application of isotope hydrograph separation to understand contributions of stormwater control measures to urban headwater streams. Hydrol. Process. 2015, 29. [CrossRef]

21. Tillinghast, E.D.; Hunt, W.F.; Jennings, G.D.; D'Arconte, P. Increasing Stream Geomorphic Stability Using Storm Water Control Measures in a Densely Urbanized Watershed. J. Hydrol. Eng. 2012, 17, 1381-1388. [CrossRef]

22. Bell, C.D.; McMillan, S.K.; Clinton, S.M.; Jefferson, A.J. Characterizing the Effects of Stormwater Mitigation on Nutrient Export and Stream Concentrations. Environ. Manag. 2017, 59. [CrossRef] [PubMed]

23. Bettez, N.D.; Groffman, P.M. Denitrification potential in stormwater control structures and natural riparian zones in an urban landscape. Environ. Sci. Technol. 2012. [CrossRef] [PubMed]

24. Strecker, E.W.; Quigley, M.M.; Urbonas, B.R.; Jones, J.E.; Clary, J.K. Determining Urban Storm Water BMP Effectiveness. J. Water Resour. Plan. Manag. 2001. [CrossRef]

25. Baird, J.; Hunt, W.; Winston, R. Evaluating the Hydrologic and Water Quality Performance of Infiltrating Wet Retention Ponds. In Proceedings of the 2014 World Environment and Water Resource Congress, Portland, OR, USA, 1-5 June 2014. [CrossRef]

26. Hathaway, J.M.; Hunt, W.F. Evaluation of Storm-Water Wetlands in Series in Piedmont North Carolina. J. Environ. Eng. 2010. [CrossRef]

27. Horst, M.; Traver, R.; Tokarz, E. BMP Pollutant Removal Efficiency. In Proceedings of the 2008 World Environment and Water Resource Congress, Honolulu, HI, USA, 12-16 May 2008. [CrossRef]

28. Bernhardt, E.S.; Heffernan, J.B.; Grimm, N.B.; Stanley, E.H.; Harvey, J.W.; Arroita, M.; Appling, A.P.; Cohen, M.J.; Mcdowell, W.H.; Hall, R.O.; et al. The metabolic regimes of flowing waters. Limnol. Oceanogr. 2018, 63, S99-S118. [CrossRef]

29. McClain, M.E.; Boyer, E.W.; Dent, C.L.; Gergel, S.E.; Grimm, N.B.; Groffman, P.M.; Hart, S.C.; Harvey, J.W.; Johnston, C.A.; Mayorga, E.; et al. Biogeochemical hot spots and hot moments at the interface of terrestrial and aquatic ecosystems. Ecosystems 2003, 6, 301-312. [CrossRef]

30. Rice, S.P.; Roy, A.G.; Rhoads, B.L. River Confluences, Tributaries and the Fluvial Network; Rice, S., Roy, A., Rhoads, B., Eds.; John Wiley \& Sons Ltd.: West Sussex, UK, 2008; ISBN 9780470026724.

31. Kiffney, P.M.; Greene, C.M.; Hall, J.E.; Davies, J.R. Tributary streams create spatial discontinuities in habitat, biological productivity, and diversity in mainstem rivers. Can. J. Fish. Aquat. Sci. 2006. [CrossRef]

32. Rice, S.P.; Kiffney, P.; Greene, C.; Pess, G.R. The Ecological Importance of Tributaries and Confluences. In River Confluences, Tributaries and the Fluvial Network; Rice, S., Roy, A., Rhoads, B., Eds.; John Wiley \& Sons Ltd.: West Sussex, UK, 2008; ISBN 9780470026724. 
33. Liu, Y.; Engel, B.A.; Flanagan, D.C.; Gitau, M.W.; McMillan, S.K.; Chaubey, I. A review on effectiveness of best management practices in improving hydrology and water quality: Needs and opportunities. Sci. Total Environ. 2017, 601-602, 580-593. [CrossRef] [PubMed]

34. Koch, B.J.; Febria, C.M.; Gevrey, M.; Wainger, L.A.; Palmer, M.A. Nitrogen Removal by Stormwater Management Structures: A Data Synthesis. J. Am. Water Resour. Assoc. 2014, 50. [CrossRef]

35. Bell, C.D.; McMillan, S.K.; Clinton, S.M.; Jefferson, A.J. Hydrologic response to stormwater control measures in urban watersheds. J. Hydrol. 2016, 541. [CrossRef]

36. Carpenter, S.R.; Caraco, N.F.; Correll, D.L.; Howarth, R.W.; Sharpley, A.N.; Smith, V.H. Nonpoint pollution of surface waters with phosphorus and nitrogen. Ecol. Appl. 1998, 8, 559-568. [CrossRef]

37. Rabalais, N.N.; Turner, R.E.; Wiseman, W.J.J. Hypoxia in the Gulf of Mexico. J. Environ. Qual. 2001, 30, 320-329. [CrossRef] [PubMed]

38. Groffman, P.M.; Altabet, M.A.; Böhlke, J.K.; Butterbach-Bahl, K.; David, M.B.; Firestone, M.K.; Giblin, A.E.; Kana, T.M.; Nielsen, L.P.; Voytek, M.A. Methods for measuring denitrification: Diverse approaches to a difficult problem. Ecol. Appl. 2006, 16, 2091-2122. [CrossRef]

39. O'Connor, B.L.; Hondzo, M.; Dobraca, D.; LaPara, T.M.; Finlay, J.A.; Brezonik, P.L. Quantity-activity relationship of denitrifying bacteria and environmental scaling in streams of a forested watershed. J. Geophys. Res. Biogeosci. 2006. [CrossRef]

40. State Climate Office of North Carolina NC Climate Retrieval and Observations Network of the Southeast Database (CRONOS). Available online: https: / climate.ncsu.edu/cronos (accessed on 4 January 2013).

41. United States Department of Agriculture-National Resource Conservation Service (USDA-NRCS). Mecklenburg County Soil Survey Report. Available online: http://websoilsurvey.nrcs.usda.gov/app/ (accessed on 4 January 2013).

42. Rice, E.W.; Baird, R.B.; Eaton, A.D.; Clesceri, L.S. Standard Methods for the Examination of Water and Wastewater; American Public Health Association, American Water Works Association, Water Environment Federation: Washington, DC, USA, 2012.

43. Bernot, M.J.; Dodds, W.K.; Gardner, W.S.; McCarthy, M.J.; Sobolev, D.; Tank, J.L. Comparing denitrification estimates for a Texas estuary by using acetylene inhibition and Membrane Inlet Mass Spectrometry. Appl. Environ. Microbiol. 2003, 69, 5950-5956. [CrossRef] [PubMed]

44. Knowles, R. Denitrification. Microbiol. Rev. 1982, 46, 43-70. [PubMed]

45. R Core Team. R: A Language and Environment for Statistical Computing; R Foundation for Statistical Computing: Vienna, Austria, 2014; ISBN 3-900051-07-0.

46. Hogan, D.M.; Walbridge, M.R. Best management practices for nutrient and sediment retention in urban stormwater runoff. J. Environ. Qual. 2007, 36, 386. [CrossRef] [PubMed]

47. Line, D.E.; White, N.M. Effects of Development on Runoff and Pollutant Export. Water Environ. Res. 2007. [CrossRef]

48. Reisinger, A.J.; Groffman, P.M.; Rosi-Marshall, E.J. Nitrogen-cycling process rates across urban ecosystems. FEMS Microbiol. Ecol. 2016, 92, fiw198. [CrossRef] [PubMed]

49. Scarlett, R.D.; McMillan, S.K.; Bell, C.D.; Clinton, S.M.; Jefferson, A.J.; Rao, S. Influence of Stormwater Control Measures on Water Quality at Nested Sites in a Small Suburban Watershed. Urban Water J. 2018. in review.

50. Rice, S.P.; Ferguson, R.I.; Hoey, T.B. Tributary control of physical heterogeneity and biological diversity at river confluences. Can. J. Fish. Aquat. Sci. 2006. [CrossRef]

51. Hedin, L.O.; von Fischer, J.C.; Ostrom, N.E.; Kennedy, B.P.; Brown, M.G.; Robertson, G.P. Thermodynamic constraints on nitrogen transformations and other biogeochemical processes at soil-stream interfaces. Ecology 1998, 79, 684-703. [CrossRef]

52. Carleton, J.N.; Grizzard, T.J.; Godrej, A.N.; Post, H.E. Factors affecting the performance of stormwater treatment wetlands. Water Res. 2001. [CrossRef]

53. Morse, N.R.; McPhillips, L.E.; Shapleigh, J.P.; Walter, M.T. The Role of Denitrification in Stormwater Detention Basin Treatment of Nitrogen. Environ. Sci. Technol. 2017. [CrossRef] [PubMed]

54. Flint, S.A.; McDowell, W.H. Effects of headwater wetlands on dissolved nitrogen and dissolved organic carbon concentrations in a suburban New Hampshire watershed. Freshw. Sci. 2015. [CrossRef]

55. Collins, K.A.; Lawrence, T.J.; Stander, E.K.; Jontos, R.J.; Kaushal, S.S.; Newcomer, T.A.; Grimm, N.B.; Cole Ekberg, M.L. Opportunities and challenges for managing nitrogen in urban stormwater: A review and synthesis. Ecol. Eng. 2010. [CrossRef] 
56. Gold, A.C.; Thompson, S.P.; Piehler, M.F. Water quality before and after watershed-scale implementation of stormwater wet ponds in the coastal plain. Ecol. Eng. 2017. [CrossRef]

57. Meyer, J.L.; Paul, M.J.; Taulbee, W.K. Stream ecosystem function in urbanizing landscapes. J. N. Am. Benthol. Soc. 2005, 24, 602-612. [CrossRef]

58. Vietz, G.J.; Walsh, C.J.; Fletcher, T.D. Urban hydrogeomorphology and the urban stream syndrome: Treating the symptoms and causes of geomorphic change. Prog. Phys. Geogr. 2015. [CrossRef]

59. Claessens, L.; Tague, C.L.; Band, L.; Groffman, P.; Kenworthy, S. Hydro-ecological linkages in urbanizing watersheds: An empirical assessment of instream nitrate loss and evidence of saturation kinetics. J. Geophys. Res. 2009, 114, G04016. [CrossRef]

60. Pomeroy, C.A.; Postel, N.A.; O’Neill, P.A.; Roesner, L.A. Development of Storm-Water Management Design Criteria to Maintain Geomorphic Stability in Kansas City Metropolitan Area Streams. J. Irrig. Drain. Eng. 2008. [CrossRef]

61. Tuttle, A.K.; McMillan, S.K.; Gardner, A.; Jennings, G.D. Channel complexity and nitrate concentrations drive denitrification rates in urban restored and unrestored streams. Ecol. Eng. 2014, 73, 770-777. [CrossRef]

62. Arango, C.P.; Tank, J.L.; Schaller, J.L.; Royer, T.V.; Bernot, M.J.; David, M.B. Benthic organic carbon influences denitrification in streams with high nitrate concentration. Freshw. Biol. 2007, 52, 1210-1222. [CrossRef]

63. McMillan, S.K.; Piehler, M.F.; Thompson, S.P.; Paerl, H.W. Denitrification of nitrogen released from senescing algal biomass in coastal agricultural headwater streams. J. Environ. Qual. 2010, 39, 274-281. [CrossRef] [PubMed]

64. Royer, T.V.; Tank, J.L.; David, M.B. Transport and fate of nitrate in headwater agricultural streams in Illinois. J. Environ. Qual. 2004, 33, 1296-1304. [CrossRef] [PubMed]

65. Inwood, S.E.; Tank, J.L.; Bernot, M.J. Patterns of denitrification associated with land use in 9 midwestern headwater streams. J. N. Am. Benthol. Soc. 2005, 24, 227-245. [CrossRef]

66. Alexander, R.B.; Boyer, E.W.; Smith, R.A.; Schwarz, G.E.; Moore, R.B. The role of headwater streams in downstream water quality. J. Am. Water Resour. Assoc. 2007, 43, 41-59. [CrossRef] [PubMed]

(C) 2018 by the authors. Licensee MDPI, Basel, Switzerland. This article is an open access article distributed under the terms and conditions of the Creative Commons Attribution (CC BY) license (http:/ / creativecommons.org/licenses/by/4.0/). 